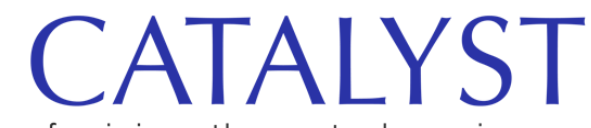

feminism, theory, technoscience

\title{
Using Feminist Theory and Social Justice Pedagogy to Educate a New Generation of Precautionary Principle Chemists
}

\author{
Grace A. Lasker \\ University of Washington Bothell \\ glasker@uw.edu \\ Nancy J. Simcox \\ University of Washington \\ nsimcox@uw.edu
}

\section{Abstract}

Students in the science classroom learn that science makes right, which devalues (whether inadvertently or very purposefully) other non-scientific areas of study and largely works against ideas of collectivism and community, especially as science "rises to the top" in collaborative partnerships and interdisciplinary research and service. Applying feminist theory and social justice pedagogy within the chemistry classroom can help focus the students' learning experiences away from hierarchical outcomes that perpetuate discriminatory practices toward change agency and the pursuit of equity, especially in regard to the design of safer chemicals. Most would agree that it is not ethically acceptable to continue to design and produce chemicals that cause adverse human health effects and environmental pollution; however, changes in the chemistry classroom to redirect this outcome have been slow. Emphasis on designing safer chemicals driven by the precautionary principle can advance the role of students and teachers as change agents in their communities. When considering feminist theory and social 
justice pedagogy in the chemistry classroom, classrooms become inclusive and learning outcomes shift toward focusing on how to reduce health disparities due to chemical exposures and how to interact with systems of domination and decision making in the workplace and beyond. New chemistry curriculum is needed in these areas to help prepare a new generation of "precautionary principle chemists" who will advocate for all of our communities.

\section{Introduction}

Faculty in health sciences, biology, environmental science, environmental justice, and public health have steadily integrated social justice and health equity pedagogy into the classroom, impacting critical consciousness, citizenship, and advocacy as well as supporting students from communities traditionally excluded from mainstream STEM programs of study and careers (Alemán \& Gaytán, 2017; Greenberg, 2017; Howard-Grenville et al., 2017; Kennedy \& Odell, 2014; Madrigal et al., 2016; Vakil, 2014; Zembylas, 2005). Yet other science disciplines such as chemistry have been slow to adopt similar strategies. Chemistry students largely lack the resources, tools, and support to combine social, political, and academic growth to take action and learn to participate in decision making that promotes a more equitable and sustainable world (Greenberg, 2017).

Applying feminist theory and social justice pedagogy within the chemistry classroom helps shift the students' learning experiences away from hierarchical outcomes that perpetuate discriminatory practices toward change agency and the pursuit of equity, especially in regard to the design of safer chemicals as a fundamental aspect of chemistry curriculum. Additionally, emphasis on designing safer chemicals and implementing environmental regulatory frameworks driven by the precautionary principle can advance the role of students and teachers as change agents in their communities. This article posits that shifting learning outcomes toward a justice-oriented curriculum grounded in feminist theory and a precautionary principle focus creates inclusive learning environments that allow students to find purpose, accomplishment, and change agency within chemistry.

\section{The History of Science}

"Science" was born of a philosophy known as positivism. This philosophy holds observation and measurement as the highest authority of valid knowledge (Trochim, 2006). Science was developed as the observation of universal laws that exist around us as a code to be cracked and controlled if we could observe and quantify these laws. This philosophy heralded empiricism (observation and measurement) as a foundational tool for scientific investigation (Trochim, 2006), 
encouraged the idea of right and wrong approaches and answers to scientific inquires (Andersson, 2017), and inaccurately purported science as unbiased and impartial (Barton, 1997). This approach has shaped the foundation of science education as well. The science classroom was born in lecture halls and laboratories with students memorizing equations and manipulating data for the pursuit of foundation and application. The science classroom supposedly mirrors the "real world," but we have since recognized that this decontextualized science removes the "why" and "so what" questions asked by students and replaces them with standards-based outcomes that exclude growth mindset development from contextualized learning experiences (Ashby \& Mensah, 2018; Buxton, 2010; King \& Ritchie, 2012; Lasker et al., 2017).

Science drills itself down into the realm of details and rout memorization at the same time it becomes larger than itself as it holds itself absolute and infallible (Millar, 2012). Students in the science classroom learn that science makes right, which devalues (whether inadvertently or very purposefully) other non-scientific areas of study (Cobern, 1994; Feinstein \& Kirchgasler, 2015) and largely works against ideas of collectivism and community especially as it "rises to the top" in collaborative partnerships and interdisciplinary research and service. Science instruction favors "the prevailing culture and structural manifestations in STEM [that] have traditionally privileged norms of success that favor competitive, individualistic, and solitary practices-norms associated with White male scientists" (Ong, Smith, \& Ko, 2017, p. 206). Decontextualized science also counters feminist thinking that rejects dualistic thinking, which simplifies complex ideas and issues into bounded areas and generates hierarchies that normalize "prevailing power relationships and [makes] them more difficult to challenge" (Ferguson, 2017, p. 271) in part due to their gendered structures (Haraway, 1988; Harding, 1986; Kahveci, 2015; Ståhl \& Hussénius, 2017). Instead, feminist thinking embraces discovery as a fluid, dynamic process rather than a cause-and-effect, static experience. It "asks how things come to be, requiring that we historicize our thinking and recognize dynamic and changing relationships rather than static entities" (Ferguson, 2017, p. 271). It is rooted in justice, freedom, and equity movements that embrace intersectionality and interdisciplinarity as fundamental aspects of inquiry, discovery, and problem solving.

Social justice pedagogy also supports students' prior learning as an important aspect of critical assessment, growth mindset development, and contextualization during the learning process (Chubbuck \& Zembylas, 2008; Dimick, 2012). Dimick (2012) identifies three areas of social justice education 
relevant to science curriculum-equity, social justice curricula and pedagogy, and socially just interrelations-that contribute positively toward student learning outcomes. Applying feminist theory and social justice pedagogy within the chemistry classroom can focus students' learning experiences away from hierarchical outcomes that perpetuate discriminatory practices toward change agency and the pursuit of equity, especially in regard to the design of safer chemicals.

\section{Justice-Oriented Chemistry Curriculum}

Chemistry faculty are largely trained on and use traditional classroom lectures and laboratory exercises that were developed decades ago in order to demonstrate foundational chemistry concepts. In doing so, they inadvertently perpetuate a system that fails to provide interactive environments where students can develop skills such as critical thinking and problem solving or engage in peer-to-peer learning (Bergtrom, 2011; Berrett, 2012; Jensen, Kummer, \& Godoy, 2015). Research overwhelmingly supports positive outcomes associated with active learning in STEM classes (Cromley, Perez, \& Kaplan, 2016; Eichler \& Peeples, 2016; King \& Richie, 2012; Prince \& Felder, 2007). According to Dr. Clarissa Dirks, co-chair of the US National Academies Scientific Teaching Alliance, "At this point it is unethical to teach any other way" (Waldrop, 2015, p. 273). We herald success in having integrated active learning into chemistry education (Goacher, Kline, Targus, \& Vermette, 2017; Henry, 2017; Hinde \& Kovac, 2001; Jardine \& Friedman, 2017; Wakeling, Green, Naiker, \& Panther, 2016) but the question is, what exactly are these students "actively learning" about in their chemistry classes?

Social justice is a point of view that supports equity in political, human, social, and economic rights (Adams, 2016) not only at the individual level but also at the organizational and institutional level (Barry, 2005). Also, environmental justice is "the fair treatment and meaningful involvement of all people regardless of race, color, national origin, or income with respect to the development, implementation, and enforcement of environmental laws, regulations, and policies" (Environmental Protection Agency, 2015, para. 1). Environmental justice is not limited to environmental or ecological rights but also incorporates labor, food, civility, climate, Indigenous rights, culture, economics, immigration, and civil rights into the movement (Cole \& Foster, 2001; Faber \& McCarthy, 2003; Schlosberg, 2013). For the most part, chemistry students are not challenged to actively connect chemistry learned in the classroom with disparities faced by communities (Lasker, 2019), but shouldn't active learning mean actively integrating life experiences into learning experiences? 
Social justice pedagogy allows acknowledgment in learning spaces that there are disparities between resources, outcomes, and opportunities among marginalized populations (Shakman et al., 2007). Faculty who apply social justice pedagogy strive to create inclusive classrooms that demonstrate equity as foundational and fundamental and use "critical, critical race, postmodern, poststructural, feminist, and multicultural education theories [to] espouse the social justice education goal" (Mthethwa-Sommers, 2014). This approach not only supports marginalized students who have experienced significant difficulties accessing higher education but also helps students recognize the global impact of their by promoting an equity- and justice-oriented framework for the context by which they learn chemistry and, ultimately, enter into the workforce.

When considering feminist theory and social justice in the chemistry classroom, learning outcomes shift toward reducing disparities within communities and "the ways in which social group differences of race and ethnicity, national origins, language, religion, gender, sexuality, class, disability, and age interact with systems of domination and subordination to privilege or disadvantage different social group members relative to each other" (Adams \& Zuniga, 2016, p. 96). It helps students recognize issues of discrimination and injustice and their role in mitigating those impacts through greener and safer chemical career aspirations (Llored \& Sarrade, 2016; Noyori, 2015; Lasker et al., 2017; Schindel Dimick, 2015). Framing curriculum using a justice-oriented pedagogy not only helps support students in finding relevancy and purpose in their program of study but also supports retention of women and underrepresented minorities in STEM and related programs, too (Conley \& Hamlin, 2009; Hansson \& Lindahl, 2010; Mills \& Ayre, 2003; Rivera Maulucci, 2013; Worthley, 1992).

Women and other underrepresented groups do not persist in STEM educational programs at the same rates as their white, male counterparts (Carlone \& Johnson, 2007; Good, Rattan, \& Dweck, 2012) and statistics support significant underrepresentation of women in the STEM workforce. The United States has made STEM enrollment among women and underrepresented minorities a priority. Millions are spent to address these inequities yet globally, women accounted for only $28.8 \%$ of those employed in scientific research and development in 2014 (UNESCO Institute of Statistics, 2017). In the US, women represented only $29 \%$ of those employed in STEM-related occupations in 2013 and only $31 \%$ of all physical science occupations (National Science Board, 2016). And salary gaps continue to exacerbate an already significant problem. According 
to the National Science Board (2016), median annual salary among science and engineering highest degree holders in 2013 put men at $\$ 80,000$ and women at $\$ 55,000$. These gaps in STEM enrollment and employment will continue to widen if changes aren't made in the classroom first.

A multidisciplinary group of participants have been investigating social and environmental justice as a framework for chemistry education at the Green Chemistry and Engineering Conference annually since 2016 to help faculty learn more about the importance of inclusive classrooms and to shift their chemistry curriculum toward justice- and equity-oriented outcomes. Over the years, faculty who have attended these meetings have integrated justice-oriented projects, courses, and undergraduate research into their chemistry and green chemistry programs. However, feedback at these symposium from participants reveals a significant barrier around the lack of American Chemical Society (ACS)

accreditation standards around social and environmental justice and the resulting difficulty of transitioning courses and programs toward a social justice and feminist theory framework. Chemistry faculty are still bound to hierarchical ACS standards that favor current oppressive systems over justice-oriented ones, and tools and resources to support faculty in transitioning their curriculum are still few and far between.

\section{Using a Precautionary Principle Focus in the Classroom}

It is no longer acceptable to continue to design and produce chemicals without a better understanding of their toxicology, health effects, and environmental consequences. Many countries are adopting new chemical policy initiatives to address the chemical burdens and disparities placed on underserved communities. For these countries, a significant amount of policy and regulations are guided by the precautionary principle. The precautionary principle was formally introduced in 1998 and defined by four central components: "taking preventive action in the face of uncertainty; shifting the burden of proof to the proponents of an activity; exploring a wide range of alternatives to possibly harmful actions; and increasing public participation in decision making" (Kriebel et al., 2001, p. 871). The precautionary principle is not new, and its implementation can lead to promoting more cost-effective alternatives to hazardous products and processes. For example, traditional models of risk assessment have been described as a barrier toward developing environmentally rigorous protections as well as perpetuating the removal of individuals and communities from decisionmaking processes around chemical design and exposure policy (Kriebel et al., 2001). In addition, current scientific practice minimizes uncertainties, ignores complex issues, and gives attention to the more quantifiable and narrowly defined 
researchable aspects of an environmental or health-equity-related problem (Tickner, 2002), further delegitimizing other non-STEM disciplines that may be able to address these larger, systems-level impacts.

In the US, chemical design processes and environmental and safety policies are reactionary, placing the burden of hazard identification on the population not the corporation, whereas the precautionary principle shifts the burden for proving the safety of chemicals onto the suppliers of chemicals and not the users (Geiser, 2015). Still, in a policy blog hosted on the American Chemistry Council's website, the precautionary principle is attacked as costly and leading to unintended regulatory consequences. (Becker, 2012). This argument does not acknowledge, nor seem to value, the immeasurable instances of disproportionate exposure to hazardous chemicals experienced by vulnerable populations such as children, low socioeconomic communities, women, and communities of color (Clark, Millet, \& Marshall, 2014; Environmental Health News, 2012; Landrigan et al., 1999; Nelson, Scammell, Hatch, \& Webster, 2012; Weiss, 2000; Woodruff, Zota, \& Schwartz, 2011).

To counter these reactionary ideologies, new tools and activities must be created and used in US STEM curriculum that complement a shift toward precautionary principle approaches that value social justice, health equity, and environmental sustainability when considering chemical design and education (Anastas \& Warner, 2000; Coish et al., 2017). In this way, faculty not only value multiple student perspectives from a variety of lived experiences as valid for constructing, retaining, and applying knowledge (University of Michigan Center for Research on Teaching and Learning, 2018) but also help students recognize their capacity for change agency around equitable justice for all.

\section{Conclusion}

Justice-oriented chemistry curriculum helps students make connections between social justice, health equity, and environmental sustainability issues with the future work they will do as chemists. Real change can occur when students shift toward precautionary principle frameworks that value equity for all. Students largely underrepresented in the science classroom can find connections between their own experiences facing injustice and inequities as they learn to advocate on behalf of their communities. Feminist theory and social justice pedagogy help faculty create inclusive classrooms that provide accessible learning experiences for all students, not just those already privileged by the science system. By helping students understand that their decisions as professionals can have real 
impacts on millions, students can shift their professional goals away from reactionary-styled thinking toward precautionary-principle supported change agency.

\section{References}

Adams, M. (2016). Pedagogical foundations for social justice education. In M. Adams \& L. A. Bell (Eds.), Teaching for diversity and social justice (3rd ed., pp. 27-54). New York, NY: Routledge.

Adams, M., \& Zuniga, X. (2016). Getting started: Core concepts for social justice education. In M. Adams \& L. A. Bell (Eds.), Teaching for diversity and social justice (3rd ed., pp. 95-130). New York, NY: Routledge.

Alemán, S. M., \& Gaytán, S. (2017). "It doesn't speak to me": Understanding student of color resistance to critical race pedagogy. International Journal of Qualitative Studies in Education, 30(2), 128-146.

Anastas, P. T., \& Warner, J. C. (2000). Green chemistry: Theory and practice. Oxford, UK: Oxford University Press.

Andersson, K. (2017). Chemistry for whom? Gender awareness in teaching and learning chemistry. Cultural Studies of Science Education, 12(2), 425-433.

Ashby, P., \& Mensah, F. M. (2018). Critical chemistry education in a private, suburban high school. Research in Science Education, 50(303-332).

https://doi.org/10.1007/s11165-018-969o-2

Barry, B. (2005). Why social justice matters. Maltan, MA: Polity Press.

Barton, A. C. (1997). Liberatory science education: Weaving connections between feminist theory and science education. Curriculum Inquiry, 27(2), 141-163.

Becker, R. (2012, May 25). Precautionary principle can do more harm than good, CPSC commissioner says [Blog post]. Retrieved from https://blog.americanchemistry.com/2012/05/precautionary-principle-can-do-moreharm-than-good-cpsc-commissioner-says/

Bergtrom, G. (2011). Content vs. learning: An old dichotomy in science courses. Journal of Asynchronous Learning Networks, 15(1), 33-44.

Berrett, D. (2012). How "flipping" the classroom can improve the traditional lecture. The Chronicle of Higher Education, 12, 1-14.

Buxton, C. A. (2010). Social problem solving through science: An approach to critical, place-based, science teaching and learning. Equity \& Excellence in Education, 43(1), 120-135.

Carlone, H. B., \& Johnson, A. (2007). Understanding the science experiences of 
successful women of color: Science identity as an analytic lens. Journal of Research in Science Teaching, 44(8), 1187-1218.

Chubbuck, S., \& Zembylas, M. (2008). The emotional ambivalence of socially just teaching: A case study of a novice urban schoolteacher. American Educational Research Journal, 45(2), 274-318.

Clark, L. P., Millet, D. B., \& Marshall, J. D. (2014). National patterns in environmental injustice and inequality: Outdoor $\mathrm{NO}_{2}$ air pollution in the United States. PloS One, 9(4), eg4431.

Cobern, W. W. (1994). Re-examining the image of science in the school science curriculum. In M. R. Matthews (Ed.), Science teaching: The role of history and philosophy of science (pp. 111-132). New York, NY: Routledge.

Coish, P., Brooks, B. W., Gallagher, E. P., Mills, M., Kavanagh, T. J., Simcox, N., ... \& Kostal, J. (2017). The molecular design research network. Toxicological Sciences, $161(2), 241-248$.

Cole, L. W., \& Foster, S. R. (2001). From the ground up: Environmental racism and the rise of the environmental justice movement. New York, NY: NYU Press.

Conley, P. A., \& Hamlin, M. L. (2009). Justice-learning: Exploring the efficacy with low-income, first-generation college students. Michigan Journal of Community Service Learning, 16(1), 47-58.

Cromley, J. G., Perez, T., \& Kaplan, A. (2016). Undergraduate STEM achievement and retention: Cognitive, motivational, and institutional factors and solutions. Policy Insights from the Behavioral and Brain Sciences, 3(1), 4-11.

Dimick, A. S. (2012). Student empowerment in an environmental science classroom: Toward a framework for social justice science education. Science Education, 96(6), 990-1012.

Environmental Health News. (2012). Environmental Health News Series: Pollution, poverty, people of color. Retrieved from

https://hefn.org/learn/resource/environmental_health_news series_pollution_povert y_people_color

Environmental Protection Agency. (2015). Environmental justice. Retrieved from http://www3.epa.gov/environmentaljustice/

Eichler, J. F., \& Peeples, J. (2016). Flipped classroom modules for large enrollment general chemistry courses: A low barrier approach to increase active learning and improve student grades. Chemistry Education Research and Practice, 17(1), 197-208. Faber, D., \& McCarthy, D. (2003). Neo-liberalism, globalization, and the struggle for 
ecological democracy: Linking sustainability and environmental justice. In J. Agyeman, R. D. Bullard, \& B. Evans. (Eds.), Just sustainabilities: Development in an unequal world (pp. 38-68). Cambridge, MA: MIT Press.

Feinstein, N. W., \& Kirchgasler, K. L. (2015). Sustainability in science education? How the Next Generation Science Standards approach sustainability, and why it matters. Science Education, 99(1), 121-144.

Ferguson, K. E. (2017). Feminist theory today. Annual Review of Political Science, 20(1), 269-286

Geiser, K. (2015). Chemicals without harm: Policies for a sustainable world. Cambridge, MA: MIT Press.

Goacher, R. E., Kline, C. M., Targus, A., \& Vermette, P. J. (2017). Using a practical instructional development process to show that integrating lab and active learning benefits undergraduate analytical chemistry. Journal of College Science Teaching, 46(3), 65-73

Good, C., Rattan, A., \& Dweck, C. S. (2012). Why do women opt out? Sense of belonging and women's representation in mathematics. Journal of Personality and Social Psychology, 102(4), 700-717.

Greenberg, D. (2017, March). Why science teachers should care about social justice. iWonder: Rediscovering School Science, 1(1), 70-73.

Haraway, D. (1988). Situated knowledges: The science question in feminism and the privilege of partial perspective. Feminist Studies, 14, 575-599.

Harding, S. (1986). The science question in feminism. Ithaca, NY: Cornell University Press.

Hansson, L., \& Lindahl, B. (2010). I have chosen another way of thinking. Science \& Education, 19(9), 895-918.

Henry, R. M. (2017). Engaging participation and promoting active learning through student usage of the internet to create notes for general chemistry in class. Journal of Chemical Education, 94(6), 710-716.

Hinde, R. J., \& Kovac, J. (2001). Student active learning methods in physical chemistry. Journal of Chemical Education, 78(1), 93-99.

Howard-Grenville, J., Nelson, A. J., Earle, A. G., Haack, J. A., \& Young, D. M. (2017). "If chemists don't do it, who is going to?" Peer-driven occupational change and the emergence of green chemistry. Administrative Science Quarterly, 62(3), 524-560.

Jardine, H. E., \& Friedman, L. A. (2017). Using undergraduate facilitators for active learning in organic chemistry: A preparation course and outcomes of the experience. 
Journal of Chemical Education, 94(6), 703-709.

Jensen, J. L., Kummer, T. A., \& Godoy, P. D. D. M. (2015). Improvements from a flipped classroom may simply be the fruits of active learning. CBE-Life Sciences Education, 14(1), ar5.

Kahveci, A. (2015). Gender perspective on affective dimensions of chemistry learning. M. Kahveci \& M. Orgill (Eds). In Affective dimensions in chemistry education (pp. 6988). Berlin: Springer,

Kennedy, T. J., \& Odell, M. R. L. (2014). Engaging students in STEM education. Science Education International, 25(3), 246-258.

King, D., \& Ritchie, S. M. (2012). Learning science through real-world contexts. B. J. Fraser, K. G. Tobin, \& C. J. McRobbie (Eds). In Second international handbook of science education (pp. 69-79). Dordrecht: Springer,

Kriebel, D., Tickner, J., Epstein, P., Lemons, J., Levins, R., Loechler, E. L., ... \& Stoto, M. (2001). The precautionary principle in environmental science. Environmental Health Perspectives, 109(9), 871-876.

Landrigan, P. J., Claudio, L., Markowitz, S. B., Berkowitz, G. S., Brenner, B. L., Romero, H., ... \& Wolff, M. S. (1999). Pesticides and inner-city children: exposures, risks, and prevention. Environmental Health Perspectives, 107(suppl 3), 431-437.

Lasker, G. A., Mellor, K. E., Mullins, M. L., Nesmith, S. M., \& Simcox, N. J. (2017). Social and environmental justice in the chemistry classroom. Journal of Chemical Education, 94(8), 983-987.

Lasker, G. A. (2019). Connecting Systems Thinking and Service Learning in the Chemistry Classroom. Journal of Chemical Education, 96, 12, 2710-2714. DOI: https://doi.org/10.1021/acs.jchemed.gboo344

Llored, J. P., \& Sarrade, S. (2016). Connecting the philosophy of chemistry, green chemistry, and moral philosophy. Foundations of Chemistry, 18(2), 125-152.

Madrigal, D. S., Minkler, M., Parra, K. L., Mundo, C., Gonzalez, J. E. C., Jimenez, R., ... \& Harley, K. G. (2016). Improving Latino youths' environmental health literacy and leadership skills through participatory research on chemical exposures in cosmetics: The HERMOSA Study. International Quarterly of Community Health Education, 36(4), 231-240.

Millar, R. H. (2012). Bending the evidence: The relationship between theory and experiment in science education. In. R. H. Miller. (Ed). Doing science: Images of science in science education, (pp. 38-61).New York, NY: Routledge.

Mills, J., \& Ayre, M. (2003). Implementing an inclusive curriculum for women in engineering education. Journal of Professional Issues in Engineering Education and 
Practice, 129(4), 203-210.

Mthethwa-Sommers, S. (2014). What is social justice education? In Narratives of social justice educators (pp. 7-25). Cham: Springer.

National Science Board. (2016). Women and minorities in the S\&E workforce. Retrieved from https://nsf.gov/statistics/2016/nsb20161/\#/report/chapter-3/women-andminorities-in-the-s-e-workforce

Nelson, J. W., Scammell, M. K., Hatch, E. E., \& Webster, T. F. (2012). Social disparities in exposures to bisphenol A and polyfluoroalkyl chemicals: a cross-sectional study within NHANES 2003-2006. Environmental Health, 11(1), 10-25.

Noyori, R. (2015). Vibrant science needed for future society. Chemistry-An Asian Journal, 10(10), 2004-2005.

Ong, M., Smith, J. M., \& Ko, L. T. (2018). Counterspaces for women of color in STEM higher education: Marginal and central spaces for persistence and success. Journal of Research in Science Teaching, 55(2), 206-245.

Prince, M., \& Felder, R. (2007). The many faces of inductive teaching and learning. Journal of College Science Teaching, 36(5), 14-20.

Rivera Maulucci, M. S. (2013). Emotions and positional identity in becoming a social justice science teacher: Nicole's story. Journal of Research in Science Teaching, 50(4), 453-478.

Schindel Dimick, A. (2015). Supporting youth to develop environmental citizenship within/against a neoliberal context. Environmental Education Research, 21(3), 390402.

Schlosberg, D. (2013). Theorising environmental justice: The expanding sphere of a discourse. Environmental Politics, $22(1), 37-55$.

Shakman, K., Cochran-Smith, M., Jong, C., Terrell, D., Barnatt, J., \& McQuillan, P. (2007, April). Reclaiming teacher quality: The case for social justice. Paper presented at the meeting of the Annual Meeting of the American Educational Research Association, Chicago, IL.

Ståhl, M., \& Hussénius, A. (2017). Chemistry inside an epistemological community box! Discursive exclusions and inclusions in Swedish National tests in Chemistry. Cultural Studies of Science Education, 12(2), 395-423.

Tickner, J. (2002). Guest editorial. Public Health Reports, 117, 493-497.

Trochim, W. M. K. (2006). Positivism \& post-positivism. Retrieved from http://www.socialresearchmethods.net/kb/positvsm.php 
UNESCO Institute of Statistics. (2017). Women in science. Retrieved from http://uis.unesco.org/en/topic/women-science

University of Michigan Center for Research on Teaching and Learning. (2018). Creating inclusive college classrooms. Retrieved from http://www.crlt.umich.edu/gsis/p3_1

Vakil, S. (2014). A critical pedagogy approach for engaging urban youth in mobile app development in an after-school program. Equity \& Excellence in Education, 47(1), 3145 .

Wakeling, L., Green, A., Naiker, M., \& Panther, B. C. (2016). An Active learning, student-centred approach in chemistry laboratories: The laboratorys as a primary learning environment. S. Rowling (ed). In Proceedings of the Australian Conference on Science and Mathematics Education (formerly UniServe Science Conference) (p. 134).

Waldrop, M. M. (2015). The science of teaching science. Nature, 523, 272-274.

Weiss, B. (2000). Vulnerability of children and the developing brain to neurotoxic hazards. Environmental Health Perspectives, 108(suppl 3), 375-381.

Woodruff, T. J., Zota, A. R., \& Schwartz, J. M. (2011). Environmental chemicals in pregnant women in the United States: NHANES 2003-2004. Environmental Health Perspectives, 119(6), 878-885.

Worthley, J. S. (1992). Is science persistence a matter of values? Psychology of Women Quarterly, 16(1), 57-68.

Zembylas, M. (2005). Science education: For citizenship and/or for social justice. Journal of Curriculum Studies, 37(6), 709-722.

\section{Author Bio}

Grace Lasker is a Senior Lecturer and Director of Health Studies at the University of Washington Bothell. Her research and teaching are centered in environmental health and social justice, epigenetics, and public health nutrition. She is also investigating the intersection of toxicology, green chemistry, and change agency in education.

Nancy Simcox is a Lecturer and the Director of the Continuing Education Programs for the UW Department of Environmental \& Occupational Health Sciences. She develops and delivers research-based education programs for practicing professionals, including industrial hygienists, physicians, nurses, safety engineers and others in the environmental, health and safety field. 
Lab Meeting 